\title{
アミノアシラーゼ多層架橋固定膜の バイオリアクターへの応用
}

\author{
中村昌則 ${ }^{1)} \cdot$ 斎藤恭— $^{1)} \cdot$ 杉田和之 $^{1)} \cdot$ 須郷高信 $^{2}$ \\ 1) 千葉大学工学部物質料工学科 婹 263-8522 千葉市稲毛区弥生町 1-33 \\ 2) 日本原子力研究所高崎研究所 荬 370-1292 高崎市綿貫町 1233
}

\section{Application of Crosslinked-Aminoacylase-Multilayered Membranes to Bioreactor}

\author{
Masanori Nakamura $^{1)}$, Kyoichi Saito ${ }^{1)}$, Kazuyuki Sugita ${ }^{1)}$ \\ and Takanobu Sugo ${ }^{2)}$
}
1) Department of Materials Technology, Chiba University, Inage, Chiba 263-8522, Japan
2) Takasaki Radiation Chemistry Research Establishment, Japan Atomic Energy Research Institute Takasaki, Gunma 370-1292, Japan

\begin{abstract}
A diethylamino group as an anion-exchange group was introduced to the poly (glycidyl methacrylate) chain grafted onto a porous hollow-fiber membrane. Subsequently, aminoacylase was adsorbed in multilayers by the graft chains. The enzyme was crosslinked by a reaction with glutaraldehyde to prevent the leakage of the enzyme from the graft chain. Then, an acetyl-DL-methionine solution ( $\mathrm{pH}$ 8.0) was permeated outward through the aminoacylase-immobilized porous hollow fiber at a permeation rate of $150 \mathrm{ml} / \mathrm{h}$. At a lower feed concentration such as $10 \mathrm{mM}, 100 \%$ conversion was attained. As the feed concentration was increased, the overall reaction was reaction-controlled. The productivity of $\mathrm{L}$-methionine was maintained at $1,500 \mu \mathrm{mol} / \mathrm{h} / \mathrm{ml}$-fiber up to space velocity of $150 \mathrm{~h}^{-1}$, where space velocity is defined as effluent volume divided by membrane volume including the lumen.
\end{abstract}

Key words : aminoacylase/multilayering/crosslinking/porous hollow-fiber membrane/L-methionine

\section{1. 緒 言}

光学異性体は, 立体構造のわずかな違いにより 生理活性が大きく異なる例が数多く知られてい
る. そのため, 医薬, 食品分野では, これらの光 学異性体を分離し, 有効な一方の光学活性体を分 取する技術の必要性が高まっている ${ }^{1)}$. 光学異性 体の一方を選択的に加水分解する機能（不斉加水 
分解能）を有する酵素アミノアシラーゼ2）を固定 化したバイオリアクターを用いて, 医薬品, 食品, 飼料としての利用価值の高い L-アミノ酸を生成 させる方法について，すでに数多くの研究が行わ れている．特に，アミノアシラーゼをイオン交換 基を導入した多糖質である DEAE-Sephadex に イオン結合させたビーズ充填力ラム法により, Lアミノ酸が工業的に生産されている ${ }^{3)}$. また，ポ リ塩化ビニル製平膜に同酵素を物理吸着により固 定化し，アミノ酸の光学分割に応用した研究も報 告されている ${ }^{4)}$.

本研究では, 中空糸状の多孔性精密ろ過膜にア ミノアシラーゼを固定化し，L-アミノ酸を生成 させる手法を提案する．本研究で作成する膜の構 造および不斉酵素反応の概念図を Fig. 1 に示す. まず，放射線グラフト重合法により，精密ろ過膜 の細孔表面にアニオン交換基を有するグラフト高 分子鎖を膜厚方向に対して一様に導入する. 次に, 導入したグラフト高分子鎖にアミノアシラーゼを 多層で吸着させる.この多層吸着は，ア二オン交 換基よ゙うしの荷電反発によりグラフト高分子鎖が 伸長し、そこにタンパク質が入り込むことによっ て起こることが示されている5 ${ }^{5}$.さらに，膜に吸 着したアミノアシラーゼ分子間を架橋剤グルタル

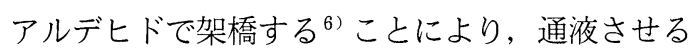
溶液の条件の変化による膜からのアミノアシラー ゼの脱離を防いだ。

本研究の方法では従来の方法に対して, 以下の 利点が考えられる. (1)アミノアシラーゼを多層固 定できるため, 膜単位表面積当たりの固定量が多 く, 高い反応効率が期待できる.(2)膜厚が $0.7 \mathrm{~mm}$ の多孔性精密ろ過膜（平均細孔径 $0.4 \mu \mathrm{m}$ ）を基 材膜として用いるため, 圧力損失が小さく, 低い 操作圧力で高い通液空間速度が得られる。および (3)柔軟なグラフト高分子鎖にアミノアシラーゼを 多点で吸着し, さらに架橋剤で固定するため, 高 次構造を崩しにくく安定性の向上が期待できる.

本研究の目的は, 上記の方法でアミノアシラー ゼ固定膜を作成し，アセチル-DL-メチオニンの 不斉加水分解性能を評価することである.

\section{2. 実 験}

\section{1 アニオン交換基を有する多孔性中空糸膜 の作成}

既報7)にしたがってアニオン交換多孔性中空糸 膜を次のように作成した (Fig. 2).グラフト重合 用の基材膜として平均細孔径が $0.4 \mu \mathrm{m}$ のポリエ チレン製の多孔性中空糸膜（外径 $3.1 \mathrm{~mm}$, 内径 $1.8 \mathrm{~mm}$, 空孔率 70\%, 旭化成工業(株製) を用い た. 基材膜に電子線を照射してラジカルを生成さ せた後, 10 (v/v)\%グリシジルメタクリレート (GMA)/メタノール溶液に $313 \mathrm{~K}$ で $15 \mathrm{~min}$ 浸 漬した. このようにして基材膜に対して重量が 2 倍の GMA グラフト重合膜を作成した。この GMA グラフト重合膜を $50(\mathrm{v} / \mathrm{v}) \%$ ジエチルア ミン (DEA) 水溶液に $303 \mathrm{~K}$ で $4 \mathrm{~h}$ 浸漬後, エ タノールアミン $(\mathrm{EA})$ に $303 \mathrm{~K}$ で $12 \mathrm{~h}$ 浸漬させ てジエチルアミノ基と 2-ヒドロキシエチルアミ ノ基を有する膜（DEA-EA 膜）を作成した。 シ エチルアミノ基と 2-ヒドロキシエチルアミノ基 の膜への導入量は滴定法で求めた. DEA-EA 膜 の諸物性を Table 1 に示す.

\section{2 膜へのアミノアシラーゼ吸着およびアミ} ノアシラーゼ分子間のグルタルアルデヒド架橋

得られた DEA-EA 膜（有効長 $70 \mathrm{~mm}$ ）に $1.5 \mathrm{mg} / \mathrm{ml}$ のアミノアシラーゼ (ブタ腎蔵由来, Sigma 社製) 溶液を透過させ, 膜にアミノアシ ラーゼをイオン交換吸着させた。実験装置を Fig. 3 に示す. アミノアシラーゼを $14 \mathrm{mM}$ のト リ又塩酸緩衝液 $(\mathrm{pH}$ 8.0) に溶かし, 膜の内面か ら外面へ透過させた. 膜からの流出液を連続的に 採取して, $280 \mathrm{~nm}$ の吸光度を測定することによ り, 流出液中のアミノアシラーゼ濃度を求めた. 実験は室温 $(298 \mathrm{~K})$ で行った. 吸着量を以下の 式から算出した。

吸着量 $[\mathrm{mg} / \mathrm{g}]=\left\{\left(\int_{0}^{v e}\left(\mathrm{C}_{0}-\mathrm{C}\right) \mathrm{dV}\right)-(\right.$ 洗浄 操作での溶出量) $\} / W$

ここで $\mathrm{C}_{0}$ は吸着操作における供給液中のアミノ アシラーゼ濃度, $\mathrm{C}$ は流出液中のアミノアシラー 
ゼ濃度, $\mathrm{V}$ は流出液量, $\mathrm{V}_{e}$ は $\mathrm{C}$ が $\mathrm{C}_{0}$ に達した ときの流出液量であり, W 燥重量である.

続いてアミノアシラーゼ吸着膜を装置から取り 外し, $0.05 \mathrm{wt} \%$ グルタルアルデヒド溶液 $(\mathrm{pH}$ 8.0)を $20 \mathrm{ml}$ 入れた試験管内に $303 \mathrm{~K}$ で $12 \mathrm{~h}$ 浸 漬させ, 膜に吸着したアミノアシラーゼ分子間を 架橋した. 反応後, 膜を再び装置に組み込み, ま ず緩衝液で膜の細孔内に残存しているグルタルア ルデヒドを洗浄した。 次に $0.5 \mathrm{M} \mathrm{NaCl}$ 溶液を 通液させて, 架橋反応で固定化されずに膜に残存 しているアミノアシラーゼを溶出させ, $280 \mathrm{~nm}$ の吸光度を測定することにより, アミノアシラー ゼ溶出量を求めた。ここで, 未架橋のアミノアシ ラーゼ吸着膜に $0.5 \mathrm{M} \mathrm{NaCl}$ 溶液を通液させる と, 吸着したアミノアシラーゼが 100\% 溶出され ることをあらかじめ確認した，架橋反応後の膜へ

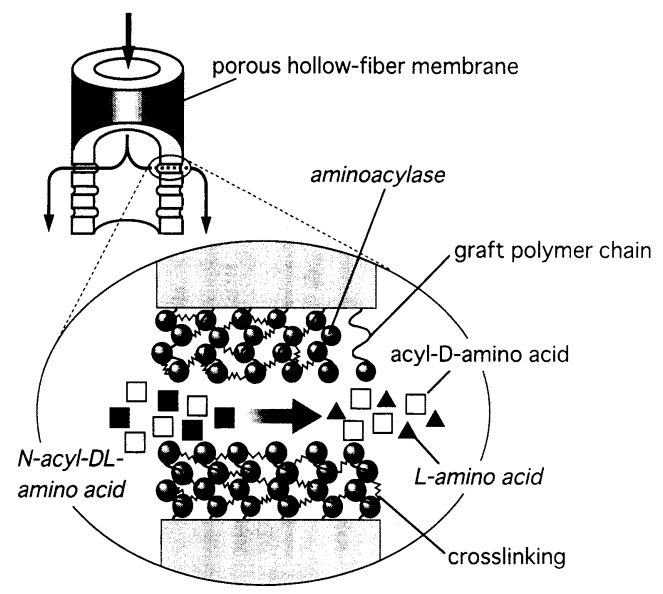

Fig. 1 Enzymatic hydrolysis of N-acyl-DLamino acid using aminoacylase-multilayered porous hollow-fiber membrane.
のアミノアシラーゼ固定量および架橋固定率を以 下の式で算出した.

架橋固定量 $[\mathrm{mg} / \mathrm{g}]=$ (吸着量 $)-(\mathrm{NaCl}$ 溶液

$$
\text { による溶出量) }
$$

架橋固定率 $[\%]=100 \times$ (架橋固定量) $/$ (吸着量)

$\mathrm{NaCl}$ 溶液を通液させた後, 再び緩衝液を通液 させて膜を洗浄し, 以下の酵素活性の測定を行っ た. 架橋反応後の膜を, 以後アミノアシラーゼ架 橋固定膜と呼ぶ。

\section{3 アミノアシラーゼ架橋固定膜の酵素活性 の測定}

アミノアシラーゼの基質としてアセチル-DLメチオニン (Ac-DL-Met) を選び, 膜の加水分解 活性を測定した. Ac-DL-Metの加水分解は, 次 式で示される（ただし, $\left.\mathrm{R}=\mathrm{CH}_{3} \mathrm{~S}\left(\mathrm{CH}_{2}\right)_{2}\right)$.

$$
\begin{aligned}
& \text { アミノアシラーゼ } \\
& \text { DL-R-CHCOOH }+\mathrm{H}_{2} \mathrm{O} \rightarrow \mathbf{L}-\mathrm{R}-\mathrm{CHCOOH} \\
& \stackrel{1}{\mathrm{NHCOCH}_{3}} \stackrel{\mathrm{NH}_{2}}{\mathrm{NH}_{2}}
\end{aligned}
$$

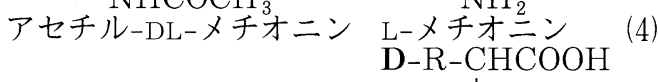

$$
\begin{aligned}
& \mathrm{NHCOCH}_{3} \\
& \text { アセチル-D-メチオニン }
\end{aligned}
$$

アミノアシラーゼ架橋固定膜 (有効長 $5.5 \mathrm{~cm}$ ) を $310 \mathrm{~K}$ の恒温室内の装置 (Fig. 3) に I 字型に セットし，シリンジポンプを用いて，Ac-DLMet 溶液 $(\mathrm{pH} \mathrm{8.0)}$ を $10 \mathrm{~m} l$ 透過させた. 流出液 を採取し,その流出液中に生成した L-Met 濃度を ニンヒドリン法 ${ }^{8)}$ で定量した。 Ac-L-Metの LMetへの転化率を以下の式で算出した.

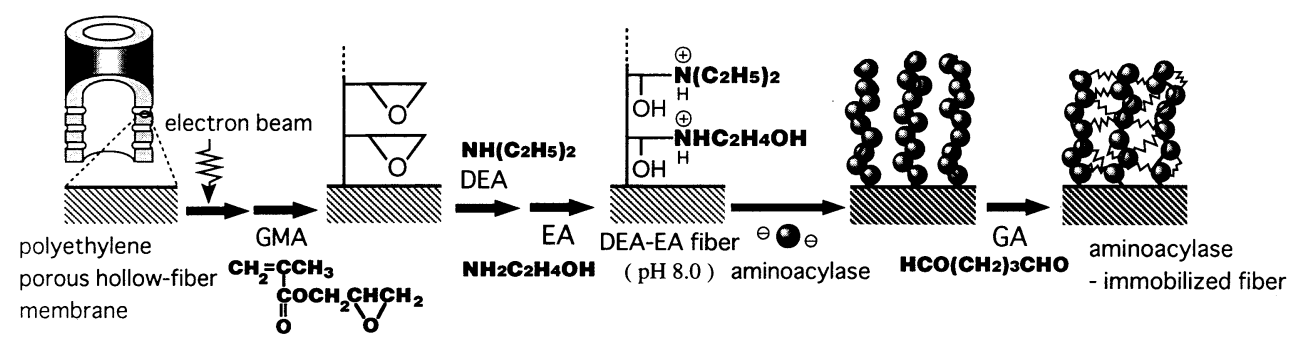

Fig. 2 Preparation scheme of aminoacylase-multilayered porous hollow-fiber membrane. 
Table 1 Properties of the DEA-EA fiber

\begin{tabular}{ll}
\hline size $[\mathrm{mm}]$ & \\
$\quad$ inner diameter & 2.4 \\
outer diameter & 4.4 \\
dry weight/wet volume $[\mathrm{g} / \mathrm{ml}]$ & 0.4 \\
functional group density $\left[\mathrm{mmol} / \mathrm{g}^{a}\right]$ & \\
$\quad$ DEA group & 2.0 \\
EA group & 1.2 \\
permeation flux ${ }^{b}[\mathrm{~m} / \mathrm{h}](\Delta \mathrm{P}=0.1 \mathrm{MPa})$ & \\
$\quad$ Tris-HCl buffer $(\mathrm{pH} 8.0)$ & 2.0 \\
specific surface area ${ }^{c}\left[\mathrm{~m}^{2} / \mathrm{g}\right]$ & 5.5 \\
\hline
\end{tabular}

${ }^{a}$ Grams of dry state of DEA-EA fiber

${ }^{b}$ Staring hollow fiber, $2.9 \mathrm{~m} / \mathrm{h}$

${ }^{c}$ BET surface area

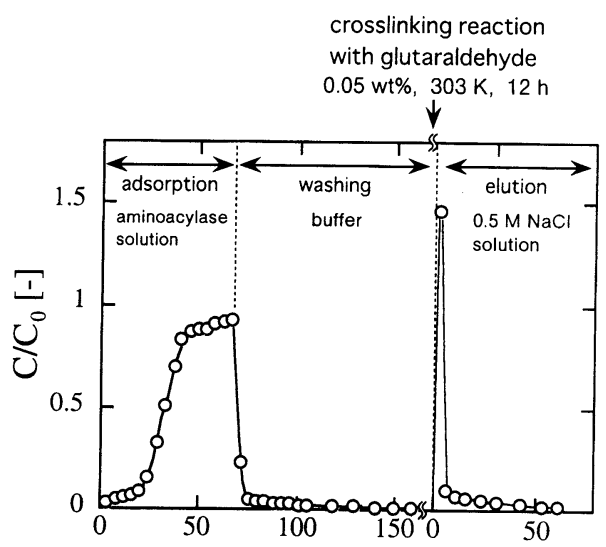

(Effluent volume) / (Membrane volume ) [-]

Fig. 4 Breakthrough curve of aminoacylase through the DEA-EA fiber and elution curve of aminoacylase after crosslinking reaction.

Feed aminoacylase conc. ; $\mathrm{C}_{o}=1.5 \mathrm{mg} /$ $\mathrm{m} l$

solvent ; $14 \mathrm{mM}$ Tris-HCl buffer $(\mathrm{pH}$ 8.0) Temperature ; $298 \mathrm{~K}$

転化率 $[\%]=100 \times($ 生成 L-Met 濃度 $) ／$

$\{$ (供給 Ac-DL-Met 濃度) /2 $\}$

また Ac-DL-Met 加水分解活性を以下の式で算 出した.

Ac-DL-Met 加水分解活性 =膜単位体積当たりの $\mathrm{L}-\mathrm{Met}$ 生成速度 $[\mu \mathrm{mol} / \mathrm{h} / \mathrm{ml}]=(\mathrm{L}-\mathrm{Met}$ 生成濃 度 $[\mu \mathrm{mol} / \mathrm{ml}]) \times($ 流量 $[\mathrm{ml} / \mathrm{h}]) /($ 膜体積 $[\mathrm{ml}])$

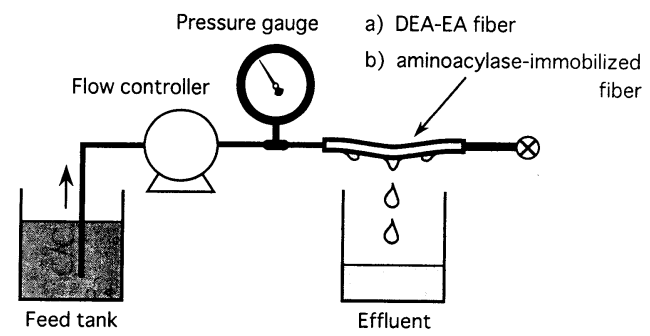

a) aminoacylase solution ( $298 \mathrm{~K}$ )

b) Ac-DL-Met solution ( $310 \mathrm{~K}$ )

Fig. 3 Experimental apparatus.

a) adsorption of aminoacylase during permeation through the DEA-EA fiber

b) enzymatic hydrolysis of Ac-DL-Met during permeation through the aminoacylaseimmobilized fiber

また, Ac-DL-Met 溶液通液時の空間速度 (Space Velocity, SV) を次式より算出した.

$\mathrm{SV}[1 / \mathrm{h}]=($ 流量 $[\mathrm{m} l / \mathrm{h}]) /($ 膜体積 $[\mathrm{m} l])$

ここで膜体積は, $\pi$ (膜の外径 $)^{2}$ (膜の長さ) $/ 4$ と した.

\section{3. 結果および考察}

\section{1 アミノアシラーゼ固定量の算出および流}

\section{量特性}

DEA-EA 膜にアミノアシラーゼ溶液を透過さ せたときの破過曲線と, 架橋反応後の溶出曲線を Fig. 4 に示す. 破過曲線から吸着量を求めると, $108 \mathrm{mg} / \mathrm{g}$-fiber $(44 \mathrm{mg} / \mathrm{ml})$ であった. また, グルタルアルデヒドを用いた架橋反応とそれに続 $く 0.5 \mathrm{M} \mathrm{NaCl}$ 溶液を用いた溶出後の膜へのア ミノアシラーゼ固定量は, $81 \mathrm{mg} / \mathrm{g}$-fiber (33 $\mathrm{mg} / \mathrm{m} l)$ であった. したがって，架橋固定率は 75\% と算出された。

アミノアシラーゼの分子構造が球形であり, か つ分子量が同一の酵素であるカルボキシペプチ ダーゼ ${ }^{9)}$ と拡散定数が等しいと仮定して算出され るストークス半径から，アミノアシラーゼ 1 分子 あたりの占有面積を求めると $7.4 \times 10^{-17} \mathrm{~m}^{2}$ で あった．また，用いた DEA-EA 膜の比表面積 は, BET 法で測定し, $5.5 \mathrm{~m}^{2} / \mathrm{g}$ であった.これ 


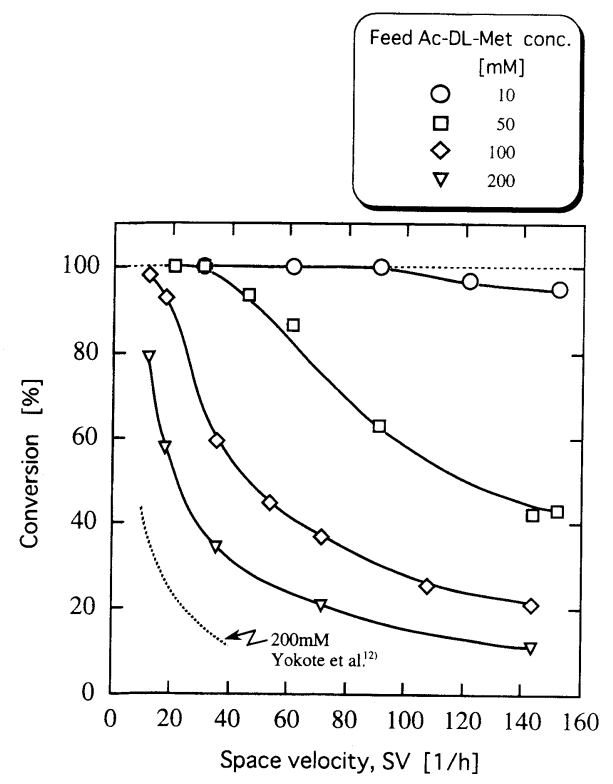

Fig. 5 Conversion from Ac-L-Met into L-Met by an aminoacylase-immobilized fiber as a function of the space velocity.

らより, アミノアシラーゼが最密充填で膜の表面 を覆ったと仮定したときの吸着量であるアミノア シラーゼの理論単層吸着量 ${ }^{10)}$ を求めると, 11 $\mathrm{mg} / \mathrm{g}$-fiber であった. 実験で得られた膜へのア ミノアシラーゼの架橋固定量は, 理論単層吸着量 の 7.4 倍であり, アミノアシラーゼを約 7 層積層 させて膜に架橋固定できた。

このアミノアシラーゼ架橋固定膜にリン酸緩衝 液を透過させたときの通液空間速度は操作圧力に 比例し, $0.03 \mathrm{MPa}$ の操作圧力下での SV は 150 $\mathrm{h}^{-1}$ に達した. 既往のアミノアシラーゼを固定し たビーズ充填力ラム法では, SV は 10〜 40 h $\mathrm{h}^{-1}$ で 操作されている11１2)．アミノアシラーゼ架橋固 定膜は, 低い操作圧力で高い SV が得られること が確認できた。

\section{2 アミノアシラーゼ架橋固定膜のアセチ} ル-DL-メチオニン加水分解活性

アミノアシラーゼ架橋固定膜に Ac-DL-Met 溶 液を透過させたときの転化率の SV による変化を Fig. 5 に示す.基質濃度が $10 \mathrm{mM}$ では, $\mathrm{SV}=90$

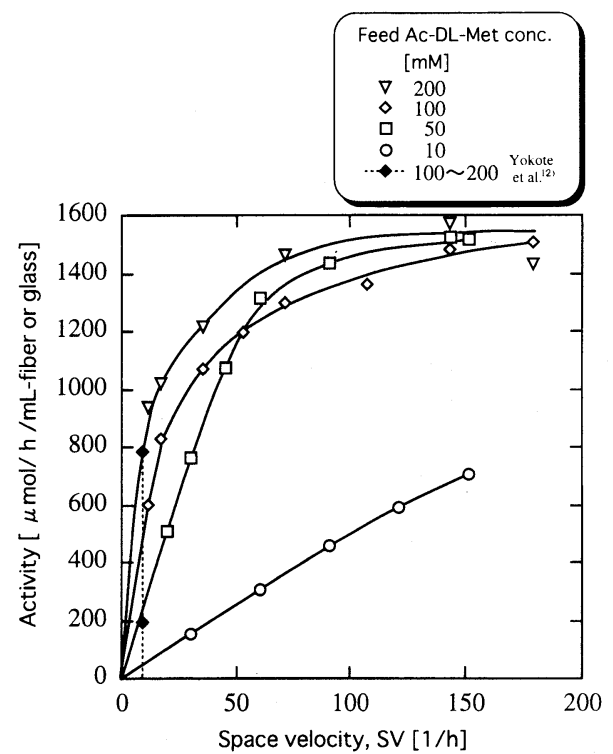

Fig. 6 Effect of substrate concentration and space velocity on the activity of immobilized aminoacylase.

$\mathrm{h}^{-1}$ まではSV に依存せず転化率は $100 \%$ であっ た。しかしながら，どの基質濃度でも SV が高く なるにつれ転化率が低下した。この結果は，アミ ノアシラーゼをアミノ基を有するガラスビーズに グルタルアルデヒドによって共有結合で固定した ビーズ充壃カラム ${ }^{12}$ (アミノアシラーゼ固定量 8〜31 mg/ml-glass) での結果と同様であった (Fig. 5 の波線部分)。これは, 高 SV では基質 の供給が過剰で, 加水分解反応が十分に進行しな いうちに基質が膜およびカラムを透過してしまう ことを示している. 同じ条件 (Ac-DL-Met 濃度 $200 \mathrm{mM})$ で, 膜とガラスビーズカラムの転化率 を比較すると, 膜を用いる本研究の方法が約 2 倍 高いことがわかった。

アミノアシラーゼの膜からの漏出の有無を調べ

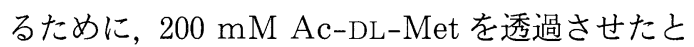
きの流出液を $310 \mathrm{~K}$ の恒温室内に 24 時間保存 し, 保存前後の液中の L-Met 濃度を比較したが, L-Met 濃度の増加はなかった。このことから， 反応操作中にアミノアシラーゼの膜からの漏出は ないことが確認できた。 
また, 実験後アミノアシラーゼ架橋固定膜を使 用した緩衝液中に浸漬し, $277 \mathrm{~K}$ の冷蔵庫内に保 存することによって, 膜作成後 10 日間にわたっ て再現性よく Ac-DL-Met を不斉加水分解できる ことが確認できた。

\section{3 アセチル-DL-メチオニン加水分解活性の ビーズ充塡カラム法との比較}

アミノアシラーゼ架橋固定膜および，アミノア シラーゼを固定したビーズ充填力ラム ${ }^{12)}$ のそれ ぞれの Ac-DL-Met 加水分解活性の比較を Fig. 6 に示す. 同じ条件 (Ac-DL-Met 濃度 100 200 $\mathrm{mM}, \mathrm{SV}=10)$ で, 膜とガラスビーズカラムの単 位体積当たりの Ac-DL-Met 加水分解活性を比較 すると, 膜では 500 800 $\mu \mathrm{mol} / \mathrm{h} / \mathrm{ml}$-fiber で あり, ガラスビーズカラムでは 192 780 $\mu \mathrm{mol} /$ $\mathrm{h} / \mathrm{m} l$-glass であることから, Ac-DL-Met の加 水分解性能は，ほぼ同等であることがわかった。 しかしながら, 多孔性膜は圧力損失が小さく, ま た転化率もビーズ充填力ラム法に比べ高い点で有 利である。

\section{4. 結 言}

多孔性中空糸膜の孔表面にア二オン交換基であ るジエチルアミノ基を付与したグラフト高分子鎖 を導入し，そのグラフト高分子鎖に酵素アミノア シラーゼを積層吸着させ, さらにグルタルアルデ ヒドで分子間を架橋したアミノアシラーゼ架橋固 定膜を作成した.この膜で光学異性体アセチルDL-メチオニンの不斉加水分解活性を評価した結 果, 次のことを明らかにした.

1）ジエチルアミノ基導入密度が $2.0 \mathrm{mmol} / \mathrm{g}$ fiber の DEA-EA 膜へのアミノアシラーゼの架 橋固定量は, $81 \mathrm{mg} / \mathrm{g}$-fiber に達した.

2) アミノアシラーゼ架橋固定膜で, Ac-DLMet の加水分解が可能であった. しかしながら, 通液空間速度が大きくなるにつれて生成する LMet 濃度が低下した。
膜 (MEMBRANE), Vol. 23 No. 6 (1998)

321

3）アミノアシラーゼ架橋固定膜の Ac-DLMet 加水分解活性は, アミノアシラーゼ固定化 ガラスビーズの活性の文献值と同等であった.

以上よりグラフト高分子鎖を導入した多孔性中 空糸膜にアミノアシラーゼを固定した膜をバイオ リアクターとして利用できることがわかった。 こ の方法は従来のビーズ充填力ラム法に比べ, 低い 操作圧力で高い空間速度が得られる点および転化 率が高い点で有利である.

\section{謝 辞}

基材膜である多孔性中空糸膜は, 旭化成工業株式会 社機能膜技術開発部の渡辺幸平, 久保田昇両氏から提 供していただきました，また，本研究の一部は文部省 科学研究費補助金（N0. 09450289）によりました.

\section{文 献}

1) 牧野成夫: PHARM TECH JAPAN, 12, 43 (1996)

2）丸尾文治, 田宮信雄監修: 酵素ハンドブック, 朝 倉書店, 586 (1982)

3) 千畑一郎: 固定化酵素, 講談社サイエンティフィ ク, 128-136 (1975)

4）東稔節治, 中村秀美 : 化学工学論文集, 14, 347-353 (1989)

5) S. Tsuneda, K. Saito, T. Sugo, K. Makuuchi: Radiat. Phys. Chem., 46, 239-245 (1995)

6) 受田浩之：化学と生物, 35, 496-504 (1997)

7) S. Tsuneda, K. Saito, S. Furusaki, T. Sugo : J. Chromatogr. A, 689, 211-218 (1995)

8) K. Hirano, I. Karube, S. Suzuki : Biotechnol. Bioeng., 19, 311-321 (1977)

9）日本生化学会編 : 生化学データブック I, 東京化 学同人, 102 (1979)

10) S. Matoba, S. Tsuneda, K. Saito, T. Sugo : Bio/Technology, 13, 795-797 (1995)

11) T. Tosa, T. Mori, N. Fuse, I. Chibata : Biotechnol. Bioeng., 9, 603-615 (1967)

12) Y. Yokote, M. Fujima, G. Shimura, S. Noguchi, K. Kimura, H. Samejima : J. Solid-Phase Biochem., 1, 1-13 (1976)

（受付 1998 年 3 月 1 日 第二稿受付 9 月 4 日 掲載決定 10 月 7 日) 